\title{
Trichoptera in Flanders (Belgium): An ecological and phylogenetic characterization of the order
}

\author{
SOPHIE C. GOMBEER*, DRIES KNAPEN \& LIEVEN BERVOETS \\ Department of Biology, Research Unit Ecophysiology, Biochemistry and Toxicology, University of Antwerp, Groenenborgerlaan 171, \\ B-2020 Antwerp, Belgium \\ (*) Corresponding author: Tel.: +32 3 2653482; fax: +32 32653497 \\ E-mail address: Sophie.Gombeer@ua.ac.be
}

Flanders is a very densely populated region in the economic heart of Europe. To monitor the anthropological impact on the biological integrity of the freshwater courses, the Flemish Environment Agency (VMM) uses the Multimetric Macroinvertebrate Index for Flanders (Gabriels et al. 2006) which was recently developed under the influence of the European Water Framework Directive (WFD, EU 2000). This multimetric tool replaces the Belgian Biotic Index (BBI: range $0=$ dramatically poor quality to $10=$ very good quality), a monitoring system based on the sensitivities to pollution of the different macroinvertebrate taxa (De Pauw \& Vanhooren 1983, De Pauw et al. 1986). Although recently replaced, the BBI has been used for the past 20 years and this extensive monitoring campaign produced a considerable amount of information on the distribution of macroinvertebrate taxa in Flemish freshwater courses. The Trichoptera (caddisflies) constitute one of these taxa. Unfortunately, determinations of caddisflies as part of the BBI monitoring, are accomplished only at the family level. Specific information on the occurrence and ecological preferences at the species level is scarce and outdated. The only comprehensive report documenting the occurrence of Trichoptera in Belgium dates back to 1984 (Stroot 1984) and since then only minor revisions and additions to the original report have been published (Stroot 1985, 1987; Stroot \& Neven 1989). Therefore, the objectives of our research are to update the old species records and to elaborate and improve the ecological and phylogenetic knowledge of the Flemish Trichoptera by (a) identifying the caddisfly species that occur in Flanders; (b) determining their present distribution; (c) detecting which environmental variables influence this distribution; (d) studying whether the relationship among these variables and the species assemblages can be used to distinguish among the ecoregions in Flanders, which are based on similarities in climate, geology, geomorphology, (geo)hydrology and soil characteristics (Sevenant et al. 2002) and (e) investigating the phylogenetic relationships among the Flemish Trichoptera and evaluating their accordance with the current taxonomic classification.

In a first part of the research, the survey focussed on small streams and brooks with good to high biological water quality. The preliminary results of this first sampling campaign are presented here. The different species assemblages are identified, the influence of the environmental variables investigated and the use of Trichoptera assemblages to discriminate among ecoregions evaluated. The first results of the phylogenetic research are also shown. They include the phylogenetic trees based on 3 different genes as well as the concatenated sequence, each time using 1 specimen per species collected during the sampling campaign of Flemish small brooks.

The locations of the sampling sites were selected based on water quality data from the Flemish Environment Agency. In this first stage of the research, the survey focused on small streams and 
brooks and, consequently, artificial as well as stagnant water bodies were omitted. Furthermore, only sampling sites with a good biological water quality (BBI $\geq 7$, www.vmm.be/geoview) were considered. The sampling sites were as evenly distributed over the Flemish territory and over the different ecoregions (as defined by Sevenant et al. 2002) as possible. In total, 67 sites were selected and locations were situated in 8 of the 12 Flemish ecoregions. Trichoptera samples were taken from late May to late July 2008 and for each sampling site 51 environmental variables were recorded, including physicochemical measurements, habitat characteristics and regional scale variables like distance to the source and land-use. The biological samples were collected by a 2 minute 'kick sampling' using a standard hand net. The specimens were stored in $100 \%$ ethanol at $-20^{\circ} \mathrm{C}$ for later identification and DNA-extraction.

Two-Way-Indicator-Species Analysis (TWINSPAN, Hill 1979) was used to classify the samples based on the caddisfly species present. Prior to Canonical Correspondence Analysis (CCA), those variables that significantly contributed to the variance in the species matrix were selected by means of a permutation-based forward selection. All ordination analyses were completed using the vegan package of the open-source, statistical programming environment R (http://vegan.r-forge.rproject.org).

Three genes were selected for phylogenetic analysis: the 1st and 3rd variable regions of the large subunit rRNA (D1 \& D3), and the 4th and 5th variable regions of the small subunit rRNA (V 4-5). The primers for these genes and the protocols for PCR amplification were based on the work of Kjer et al. (2001, 2002). Each gene was amplified and sequenced for 1 specimen per species. For each gene separately, as well as for the concatenated dataset, a phylogenetic tree was constructed through Bayesian analyses using MrBayes 3.1 (Huelsenbeck \& Ronquist 2001). The Akaike information criterion of MrModeltest (Nylander 2004) was used to select the DNA substitution models. The generated phylogenetic trees were then compared with each other and with the phylogenetic hypotheses found in literature.

Trichoptera were found at 46 of the selected locations and a total of 38 different species belonging to 12 families were identified. After 4 divisions, the TWINSPAN analysis generated 6 distinct clusters, each containing 3 to 17 sampling sites (Fig. 1). For each division, indicator species were appointed. There was no overlap of indicator species among the TWINSPAN groups.

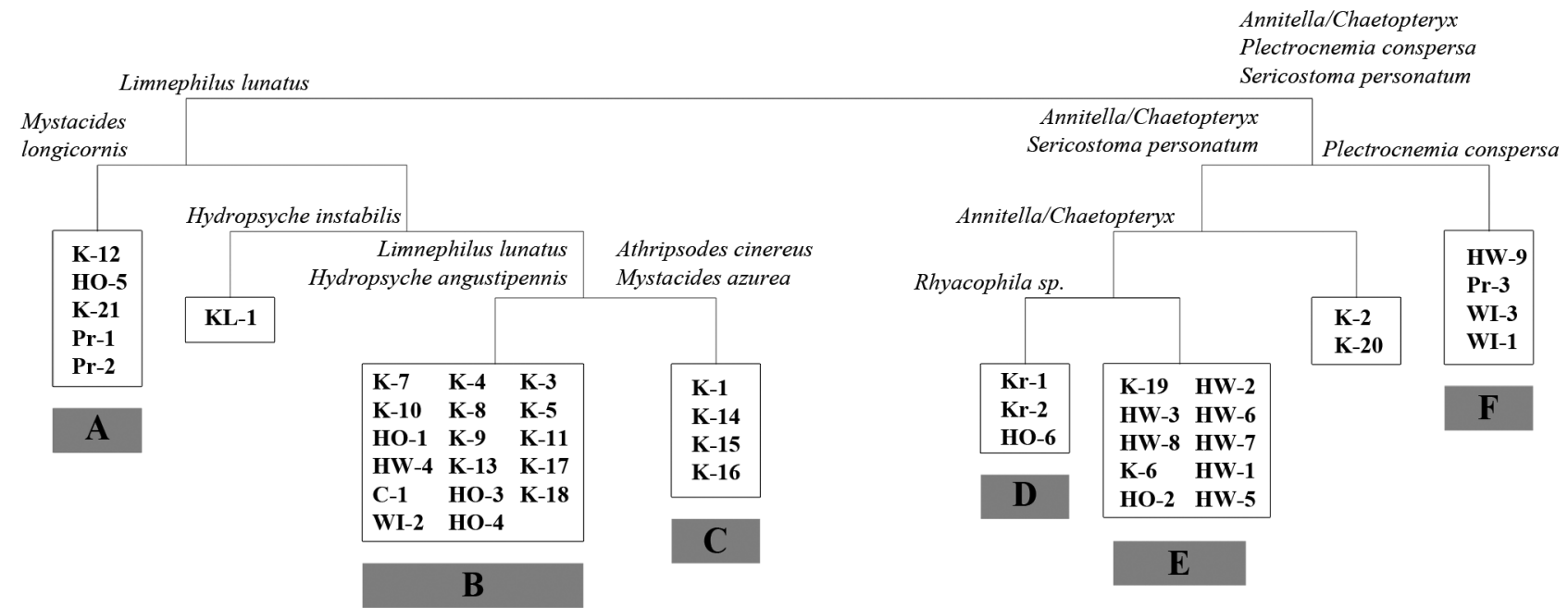

FIGURE 1. The different Trichoptera communities as identified by Two-Way-Indicator-Species Analysis. For each division the indicator species are displayed. The letters in the sampling codes indicate the different ecoregions ( $\mathrm{Pr}=\mathrm{Pleistocene}$ river valley, $\mathrm{C}=$ cuesta, $\mathrm{K}=$ Campine ecoregion, WI=western interfluvial, HW=western hill zone, $\mathrm{HO}=$ eastern hill zone, $\mathrm{KL}=$ chalk loam area, $\mathrm{Kr}=$ chalk area). 
Ten of the 51 environmental variables were statistically significant in explaining trichopteran species distribution. These 10 variables, as well as the mean and standard deviation for each TWINSPAN cluster, are listed in Appendix 1. The individual variables are plotted in Figure $2 \mathrm{~b}$ while the 2 gradients created by these environmental variables are visualized in Figure 2a; one vegetationrelated gradient from the presence of submerged vegetation towards an important percentage-shadecover by adjacent trees, and a second size-related gradient from larger, higher order streams towards sources and upper-stream sections. Both gradients are known to be important in shaping Trichoptera species assemblages (Wiberg-Larsen et al. 2000, Arscott et al. 2003, Bonada et al. 2005, Urbanič \& Toman 2007).

The CCA plot also shows that the different communities identified by the TWINSPAN analysis also separate when the environmental variables are taken into account (Fig. 2a). The different species assemblages can thus be characterized by indicator species as well as by environmental conditions. In other words, the clusters based on the community structure also differ in their environmental characteristics. In Figure 2b, the sampling sites are replaced by their ecoregion and here 2 obvious clusters can be detected: 1 containing the sites of the western hill ecoregion, and 1 containing the Campine ecoregion sampling sites. The latter is characterized by a larger stream size as well as higher temperatures, which is a specific characteristic of this ecoregion where a microclimate prevails (Sevenant et al. 2002). The samples of the eastern hill ecoregion also form a cluster which overlaps with the 2 other ecoregions between which it is situated (see inset Fig. 2). Trichopteran communities can thus, to a certain extent, be used to distinguish among ecoregions and their relative location on the CCA plot corresponds to their location on the topographic map (Fig. 2b).
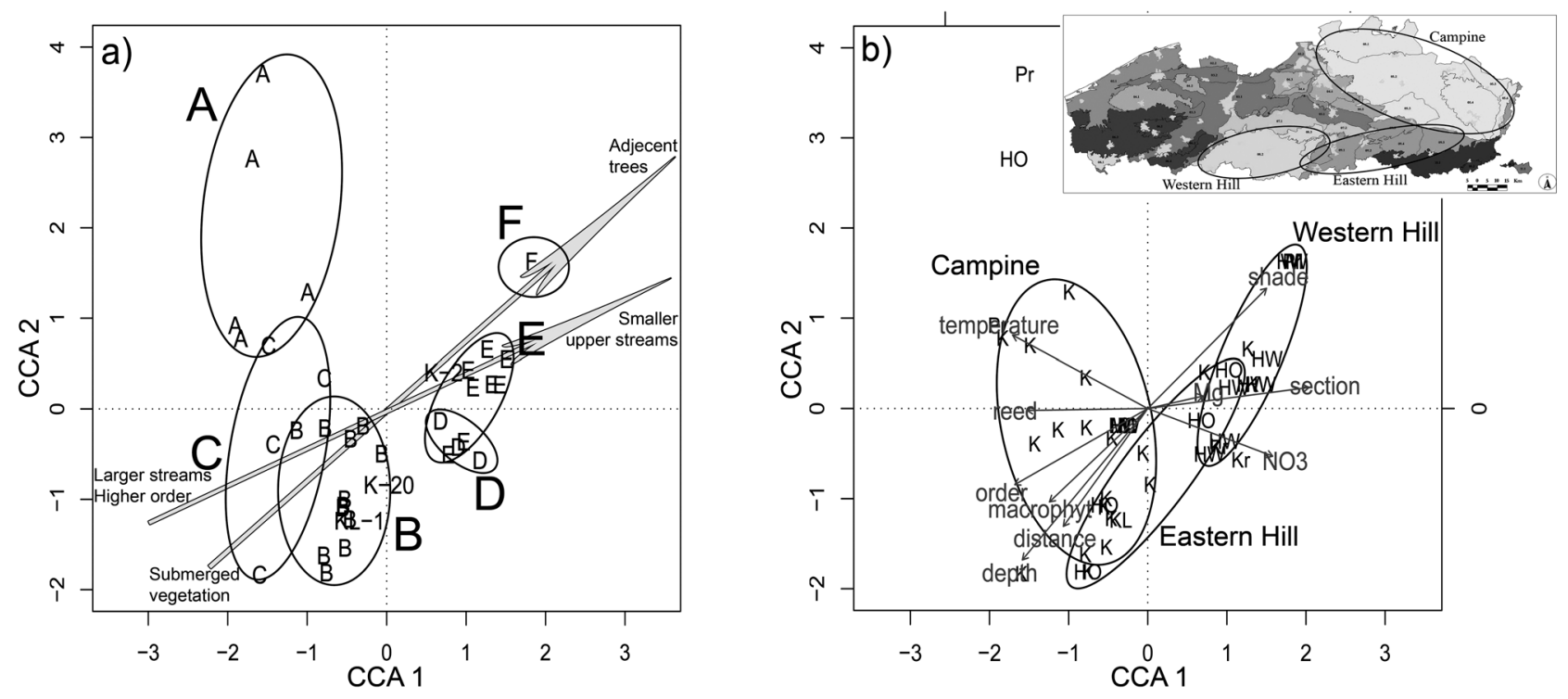

FIGURE 2. Ordination diagram of the Canonical Correspondence Analysis carried out using the $\ln (x+1)$ species matrix and the standardised significant environmental variables displaying a) the different Two-Way-Indicator-Species Analysis groups and their relation with the environmental gradients (based on the variables plotted in $2 b$ ); b) the sampling sites plotted as the ecoregion in which they are located (see Figure 1 for ecoregion codes). Inset: A map of Flanders showing the location of the Campine, western hill and eastern hill ecoregions.

Based on the generated DNA sequences for the 3 genes (D1, D3, V4-5), Bayesian analyses were undertaken to investigate the phylogenetic relationships among the Trichoptera and whether the monophyletic status of the different higher order taxa was comparable with the updated phylogeny 
based on DNA sequences as well as morphological data as presented by Holzenthal et al. (2007). Table 1 summarizes the posterior probabilities for each of the clades identified by Holzenthal et al. (2007) for all 3 genes separately as well as for the concatenated sequence. Considering the posterior probabilities for the different analyses, the only consistent factor is the well-supported recovery of the Rhyacophilidae and the total lack of recovery of the Spicipalian suborder.

TABLE 1. The posterior probabilities for the different clades as generated by the Bayesian analyses for all 3 genes separately as well as for the concatenated sequence $(\mathrm{NR}=$ not recovered, $\mathrm{NS}=$ not supported).

\begin{tabular}{lcccc}
\hline \multirow{2}{*}{ Clades } & \multicolumn{2}{c}{ Support for monophyly based on the different genetic markers } \\
& D1 & D3 & V 4-5 & Joint \\
\hline Spicipalpia & NR & NR & NR & NR \\
Rhyacophilidae & 99 & 100 & 100 & 100 \\
Hydroptilidae & 99 & 99 & NS & 100 \\
Annulipalpia & 99 & 81 & NR & 100 \\
Integripalpia & NR & NR & 97 & NR \\
Plenitentoria & 50 & NR & 71 & NR \\
Brevitentoria & 100 & NR & 92 & 100 \\
\hline
\end{tabular}

Of all sequenced genes, the D3 gene was the shortest gene with only 158 base pairs (bp). The gene seems to have a limited resolution at the higher taxonomic level and appears to be a lesssuitable marker to resolve the basal relationships among the caddisfly taxa. The 4th through the 5th variable region was the longest gene sequenced (454 bp) and was the only one that supported the monophyletic status of the Integripalpia. The resulting tree for the concatenated sequence is shown in Figure 3, in which only the highly supported clades are indicated by brackets. When comparing the results of the concatenated data with the separate markers (Table 1), it seems that D1 is the gene that most influences the concatenated tree. Finally, the obtained Flemish Trichoptera phylogeny and the phylogenetic tree constructed by Holzenthal et al. (2007) seem to correspond with respect to the monophyly of the Annulipalpia and the non-recovery of the Spicipalpia, which appear to be polyphyletic. However, in contrast to the data available in literature, the present data refute the monophyly of the Integripalpia, which seems paraphyletic due to the inclusion of the Rhyacophilidae (Fig. 3).

The data of this first sampling campaign comprising only small brooks indicated that 10 environmental variables were significantly related to the trichopteran species assemblages, including stream-size related variables, in-stream physicochemical properties as well as characteristics associated with vegetation. A distinct relationship exists among these environmental gradients and the species assemblages and caddisfly abundances change with environmental variables. Provided enough data are available, this relationship between species and environmental variables can be used to distinguish among ecoregions.

Although this first phylogenetic analysis of the Flemish Trichoptera was limited to include only 3 genes and just 1 specimen per species, the phylogenetic analysis seems to agree with recent phylogenetic hypotheses with respect to the monophyly of the Annulipalpia and the nonmonophyletic status of the Spicipalpia which tend to be polyphyletic. However, the Integripalpia were not confirmed as an independent clade, but appear to be paraphyletic. 


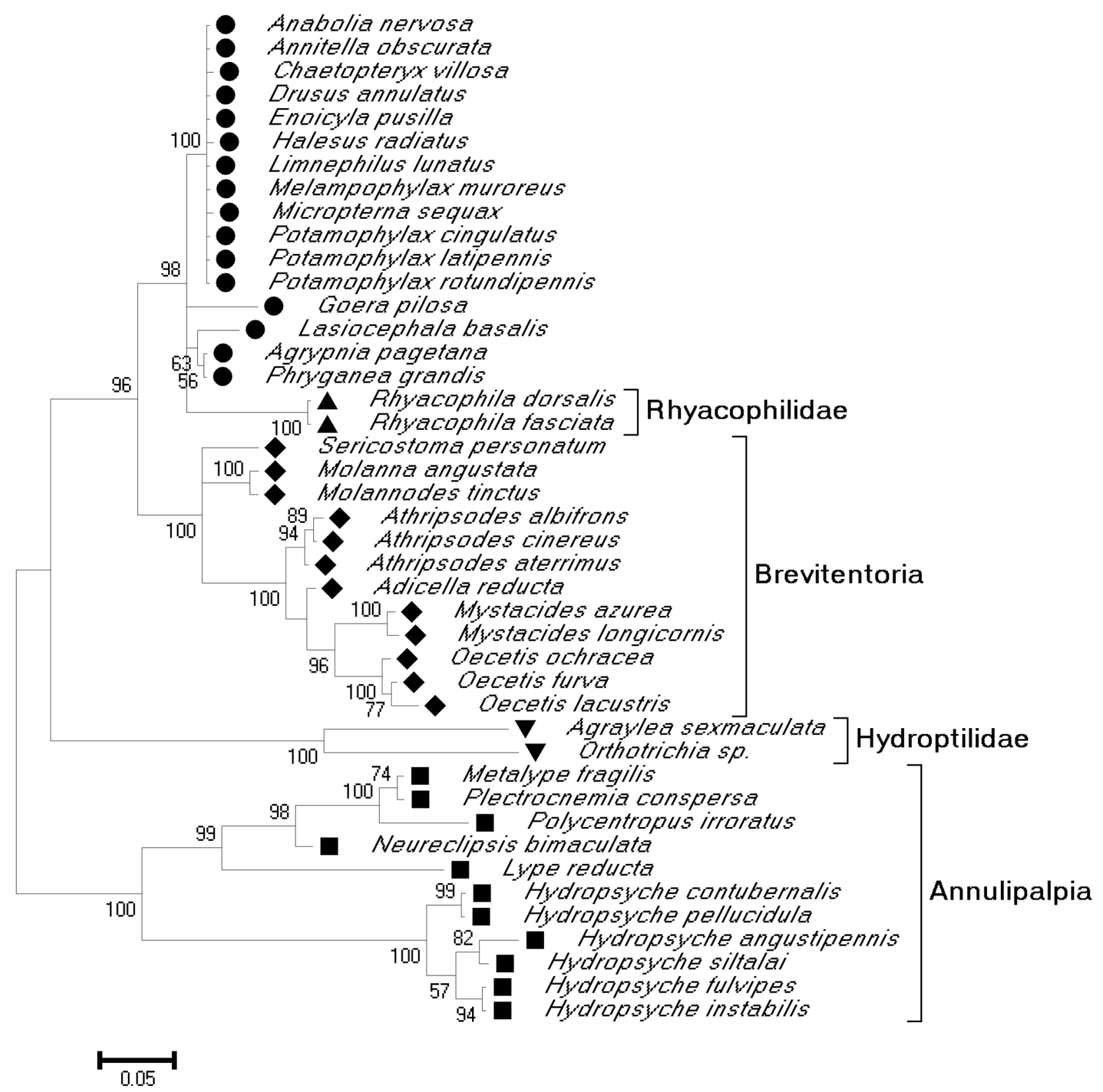

FIGURE 3. The Maximum Likelihood tree resulting from the Bayesian analysis using the concatenated sequence. Species belonging to the same higher order taxon are preceded by the same symbol: Integripalpia $=$ Plenitentoria $(\bullet)+$ Brevitentoria ( $\bullet$; Annulipalpia $(\boldsymbol{\bullet})$; Spicipalpia $=$ Rhyacophilidae $(\boldsymbol{\Delta})+$ Hydroptilidae $(\boldsymbol{\nabla})$.

\section{References}

Arscott, D.B., Keller, B., Tockner, K. \& Ward, J.V. (2003) Habitat structure and Trichoptera diversity in two headwater flood plains, NE Italy. International Review of Hydrobiology, 88, 255-273.

Bonada, N., Zamora-Muñoz, C., Rieradevall, M. \& Prat, N. (2005) Ecological and historical filters constraining spatial caddisfly distribution in Mediterranean rivers. Freshwater Biology, 50, 781-97.

De Pauw, N. \& Vanhooren, G. (1983) Method for biological quality assessment of watercourses in Belgium. Hydrobiologia, 100, 153-68.

De Pauw, N., Roels, D. \& Fontoura, A.P. (1986) Use of artificial substrates for standardized sampling of macroinvertebrates in the assessment of water quality by the Belgian Biotic Index. Hydrobiologia, 133, $237-258$. 
European Commission (2000) Directive 2000/60/EC of the European Parliament and Council establishing a framework for community action in the field of water policy. Official Journal of the European Communities, L327, 1-72.

Gabriels, W., Goethals, P.L.M. \& De Pauw, N. (2006) Development of a multimetric assessment system based on macroinvertebrates for rivers in Flanders (Belgium) according to the European Water Framework Directive. International Association of Theoretical and Applied Limnology, 29, 2279-2282.

Hill, M.O. (1979) TWINSPAN - a FORTRAN Program for Arranging Multivariate Data in an Ordered Two-Way Table by Classification of the Individuals and Attributes. Ecology and Systematics, Cornell University, Ithaca, New York, 90 pp.

Holzenthal, R.W., Blahnik, R.J., Prather, A.L. \& Kjer, K.M. (2007) Order Trichoptera Kirby, 1813 (Insecta), caddisflies. Zootaxa, 1668, 639-98.

Huelsenbeck, J.P. \& Ronquist, F. (2001) MRBAYES: Bayesian inference of phylogenetic trees. Bioinformatics, 17, 754-755.

Kjer, K.M., Blahnik, R.J. \& Holzenthal, R.W. (2001) Phylogeny of Trichoptera (caddisflies): Characterization of signal and noise within multiple datasets. Systematic Biology, 50, 781-816.

Kjer, K.M., Blahnik, R.J. \& Holzenthal, R.W. (2002) Phylogeny of caddisflies (Insecta, Trichoptera). Zoologica Scripta, 31, 83-91.

Nylander, J.A.A. (2004) MrModeltest v2. Program distributed by the author. Evolutionary Biology Centre, Uppsala

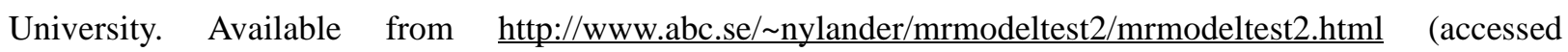
18.06.2009).

Stroot, P. (1984) Les Trichoptères de Belgique et des regions limitrophes (225 cartes). Institut Royal des Sciences Naturelles de Belgique, Bruxelles, 75 pp.

Stroot, P. (1985) Actualisation du catalogue des Trichoptères de Belgique. Société royale belge d'Entomologie, Bruxelles, $61 \mathrm{pp}$.

Stroot, P. \& Neven, B. (1989) A propos de la présence Belgique de Molannodes tinctus (Zetterstedt, 1840), trichoptère nouveau pour la faune Belge. Bulletin de l'Institut Royal des Sciences Naturelles de Belgique, 58, 259-269.

Sevenant, M., Menschaert, J., Couvreur, M., Ronse, A., Antrop, M., Geypens, M. , Hermy, M., De Blust, G. (2002) Ecodistricten : Ruimtelijke eenheden voor gebiedsgericht milieubeleid in Vlaanderen : Deel II : Afbakening van ecodistricten en ecoregio's : Verklarende teksten. Ministerie van de Vlaamse Gemeenschap, Brussels, 221 pp.

Urbanič, G. \& Toman, M.J. (2007) Influence of environmental variables on stream caddis larvae in three Slovenian ecoregions: Alps, Dinaric Western Balkans and Pannonian Lowland. International Review of Hydrobiology, 92, 582-602.

Wiberg-Larsen, P., Brodersen, K.P., Birkholm, S., Gron§, P.N. \& Skriver, J. (2000) Species richness and assemblage structure of Trichoptera in Danish streams. Freshwater Biology, 43, 633-647. 


\section{Appendices}

APPENDIX 1. Mean values and standard deviations of all statistically significant environmental variables for the groups formed during the first 4 divisions of the TWINSPAN.

TWINSPAN group

\begin{tabular}{|c|c|c|c|c|c|c|c|c|}
\hline $\begin{array}{l}\text { Environmental variable and } \\
\text { the unit of measurement }\end{array}$ & $\begin{array}{l}\text { Abbreviation used } \\
\text { in Figure 2b }\end{array}$ & & $\mathbf{A}$ & B & $\mathbf{C}$ & D & $\mathbf{E}$ & $\mathbf{F}$ \\
\hline Distance to the source & Distance & mean & 5,1 & 9,8 & 5,1 & 2,7 & 1,6 & 0,6 \\
\hline$(\mathrm{km})$ & & SD & 4,2 & 9,6 & 3,6 & 0,2 & 0,7 & 0,6 \\
\hline \multirow[t]{2}{*}{ Strahler order } & Order & mean & 2,4 & 2,3 & 2,8 & 1,7 & 1,9 & 1,0 \\
\hline & & $\mathrm{SD}$ & 0,9 & 0,8 & 0,5 & 0,6 & 0,6 & 0,0 \\
\hline Stream section & Section & mean & 2,0 & 2,2 & 1,5 & 2,7 & 3,2 & 3,8 \\
\hline $\begin{array}{l}(1=\text { lower, } 2=\text { middle } \\
3=\text { upper, } 4=\text { source })\end{array}$ & & SD & 1,0 & 0,8 & 0,6 & 1,5 & 0,4 & 0,5 \\
\hline Stream depth & Depth & mean & 0,30 & 0,52 & 0,39 & 0,23 & 0,21 & 0,14 \\
\hline$(\mathrm{m})$ & & SD & 0,22 & 0,23 & 0,24 & 0,08 & 0,13 & 0,07 \\
\hline Water temperature & Temperature & mean & 18,2 & 16,4 & 16,7 & 14,7 & 14,4 & 16,0 \\
\hline$\left({ }^{\circ} \mathrm{C}\right)$ & & SD & 1,3 & 2,1 & 1,6 & 1,7 & 1,8 & 2,5 \\
\hline Concentration of nitrate & NO3 & mean & 0,4 & 2,2 & 1,4 & 8,2 & 5,2 & 8,2 \\
\hline$(\mathrm{mg} / 1 \mathrm{NO} 3-\mathrm{N})$ & & SD & 0,5 & 1,6 & 0,9 & 4,2 & 3,4 & 7,0 \\
\hline $\begin{array}{l}\text { Shade cover by overhanging } \\
\text { trees when sun in zenith }\end{array}$ & Shade & mean & 58 & 25 & 45 & 67 & 71 & 63 \\
\hline$(\%)$ & & SD & 32 & 26 & 41 & 21 & 30 & 40 \\
\hline Magnesium & $\mathrm{Mg}$ & mean & 6,434 & 7,272 & 5,526 & 6,007 & 9,675 & 11,603 \\
\hline$(\mathrm{mg} / \mathrm{l})$ & & SD & 1,758 & 2,175 & 2,049 & 3,830 & 5,540 & 6,519 \\
\hline $\begin{array}{l}\text { Surface area covered by } \\
\text { reeds, grasses and irises }\end{array}$ & Reed & mean & 1,0 & 0,8 & 1,0 & 0,3 & 0,4 & 0,5 \\
\hline$(1=$ present, $0=$ absent $)$ & & SD & 0,0 & 0,4 & 0,0 & 0,6 & 0,5 & 0,6 \\
\hline $\begin{array}{l}\text { Surface covered by } \\
\text { submerged macrophytes }\end{array}$ & Macrophytes & mean & 0,8 & 0,8 & 1,0 & 0,7 & 0,2 & 0,5 \\
\hline$(1=$ present, $0=$ absent $)$ & & SD & 0,4 & 0,4 & 0,0 & 0,6 & 0,4 & 0,6 \\
\hline
\end{tabular}

